\title{
FACTORS INFLUENCING NON-PERFORMING FINANCING (NPF) AT SHARIA BANKING
}

\author{
JAENAL EFFENDI ${ }^{1}$, USY THIARANY ${ }^{2}$, \\ TITA NURSYAMSIAH ${ }^{3}$
}

Bogor Agricultural University

\section{Abstract}

The risk of financing is the risk caused by the failure of the customers to fulfill their obligations. Non-performing financing (NPF) is a representation of financing risk that is channeled and has a direct impact on bank profitability. The value of NPF tends to increase annually with a value that is already close to the maximum limit set by Bank Indonesia of 5 percent. This condition is able to lead to the inefficiency of the banking system and in the long run, will have an impact on the sustainability of the bank. Therefore, the analysis of NPF factors should be conducted as a preventive measure and a risks controller of business activities. This research analyzes the factors influencing NPF at sharia banking (BUS) using a quarterly datafrom first quarter of 2012 until third quarter 2016. Method used in this research is panel data analysis. The result of analysis shows that the factors influencing NPF negatively and significantly are ratio of revenue sharing financing (RR), Return on Assets (ROA), inflation, Capital Adequacy Ratio (CAR) and Banksize while Gross Domestic Product (GDP) and Operating Cost to Operating Income (BOPO) have a significant positive effect.

Risiko pembiayaan adalah risiko yang disebabkan oleh adanya kegagalan nasabah dalam memenuhi kewajibannya. Non-Performing

Corresponding author; email: ${ }^{1}$ jaenfendi@gmail.com, ${ }^{2}$ thiaranyusy@ymail.com, 3titanursyamsiah@apps.ipb.ac.id

ISSN 0852-7172 (p) 2461-064X (e)

(C) 2017 Walisongo: Jurnal Penelitian Sosial Keagamaan

http://journal.walisongo.ac.id/index.php/walisongo 
Financing (NPF) merupakan representasi dari risiko pembiayaan yang disalurkan dan berdampak langsung pada profitabilitas perbankan. Nilai NPF yang cenderung meningkat setiap tabunnya dengan nilai yang sudah mendekati batas maksimum yang telah ditetapkan oleh Bank Indonesia yaitu sebesar 5 persen dapat menyebabkan inefisiensi perbankan dan dalam jangka panjang akan berdampak pada kelangsungan bank. Maka dari itu, analisis faktor-faktor NPF perlu ditinjau sebagai upaya pencegahan dan untuk mengendalikan risiko dari kegiatan usaba. Penelitian ini menganalisis faktor-faktor yang memengarubi NPF pada Bank Umum Syariah (BUS) dengan menggunakan data kuartal dari kuartal I 2012 hingga kuartal III 2016. Metode yang digunakan dalam penelitian ini adalah analisis data panel. Hasil analisis menunjukkan bahwa faktor-faktor yang memengarubi NPF secara negatif dan signifikan adalah RR, ROA, inflasi, CAR dan Banksize sedangkan GDP dan BOPO berpengaruh positif signifikan.

Keywords: panel data analysis; sharia bank; financing; risk.

\section{Introduction}

The banking industry is one of the most important components in building the national economy. Indonesia implemented a dual banking system after the issuance of Law No. 10 of 1998. The dual banking system is a system that allows conventional banks and sharia banks to operate side by side. Since then, the government and Bank Indonesia have given a great commitment and adopted various policies to regulate, supervise and develop Islamic banks. The developments of sharia banking in Indonesia is an embodiment of the public demand for the needs of an alternative banking system, in addition providing health financial services and also sharia principles. The sharia banking is able to benefit the banks in the collection of third-party funds (DPK), which will also affect the growth of assets and financing. 
The development of total assets, deposits, financing of Islamic Banking (BUS) and Sharia Business Unit (UUS)

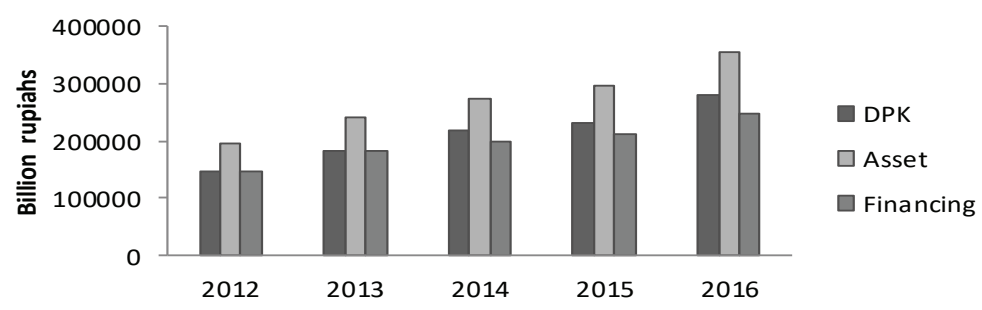

Source: Statistik Perbankan Syariah OJK 2016

Figure 1 shows that sharia banking has increased total assets, deposits and financing annually. The total assets of 195018 billion rupiahs in 2012 and in 2016 reached 356504 billion rupiahs. On the DPK side, the value in 2012 amounted to 147512 billion rupiahs and reached 279335 billion rupiahs in 2016 . When the bank has large total assets and deposits, it is able to expand its financing so that the financing increased, which in 2016 reached 248007 billion rupiahs. The greater the financing disbursed, the greater the level of profit sharing and profit margins to be accepted by Islamic banks. The efficiency made by having larger financing may increase the profit of sharia banks. In addition, financing is the main commercial activity conducted by sharia banks since its principal to develop the real sector. Therefore, financing to deposit (FDR) ratio in sharia banking is on average 87.65 percent in 2016 (OJK 2017). It implies most of the deposit fund is used for financing activities. This indicates that the financing is the main activity and the main indicator to measure the development of sharia banking.

Along with the developments of sharia banking especially on the financing side, sharia base will face various types of risk 
with varying levels of complexity attached to their business activities. One risk that has a major impact is the risk of financing. The risk of financing is the risk caused by the failure of the customers to fulfill their obligations.

Non-performing financing (NPF) is a representation of financing risk and has a direct impact on bank profitability. This is supported by the results of the research by (Rahman and Rochmanika 2012), which shows that the ratio of NPF negatively affects Return on Assets (ROA). Based on sharia banking system data from the Financial Services Authority (OJK), Islamic banking NPF is increasing in every year (Figure 2).

Figure 2

Development of NPF of Sharia Banking (BUS) and Sharia Business Unit (UUS)

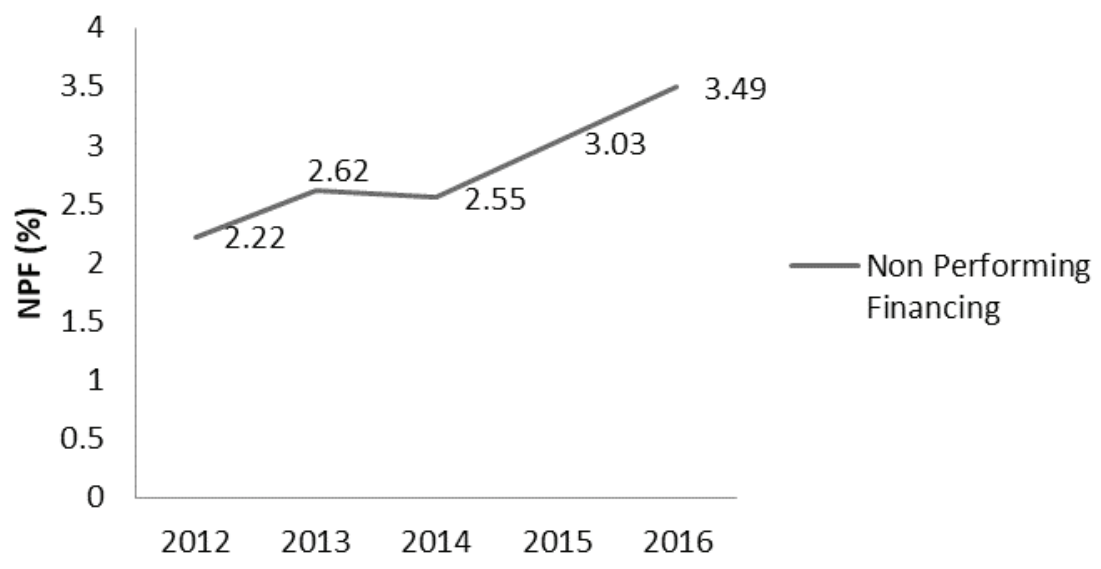

Source: Statistik Perbankan Syariah OJK 2016

Various types of financing have been offered by sharia banks to meet the needs of its customers. In practice, sharia banks run financing with several kinds of contracts. According to the sharia banking statistics of the financial services authority, the main pattern of financing that dominates in sharia banking is the prin- 
ciple of buying and selling (Murabaha) and the principle of profit sharing (musyarakah and mudaraba). This is shown in Table 1.

Table 1

Composition of financing of Sharia Banking (BUS) and Sharia Business Unit (UUS) based on the contract (billions rupiahs)

\begin{tabular}{lrrrrr}
\hline \multicolumn{1}{c}{ Akad } & \multicolumn{1}{c}{$\mathbf{2 0 1 2}$} & \multicolumn{1}{c}{2013} & \multicolumn{1}{c}{$\mathbf{2 0 1 4}$} & \multicolumn{1}{c}{2015} & \multicolumn{1}{c}{2016} \\
\hline Mudharabah & 12023 & 13625 & 14354 & 14820 & 15292 \\
Musyarakah & 27667 & 39874 & 49387 & 60713 & 78421 \\
Murabahah & 88004 & 110565 & 117371 & 122111 & 139536 \\
Salam & 0 & 0 & 0 & 0 & 0 \\
Istishna & 376 & 582 & 633 & 770 & 878 \\
Ijarah & 7345 & 10481 & 11620 & 10631 & 9150 \\
Qardh & 12090 & 8995 & 5965 & 3951 & 4731 \\
Total & 147505 & 184122 & 199330 & 212996 & 234643 \\
\hline
\end{tabular}

Source: Statistik Perbankan Syariah OJK 2016

Based on Table 1, total financing increases annually from 147.505 billion rupiahs in 2012 to 234.643 billion rupiahs in 2016. Table 1 shows that from 2012 to 2016 financing with murabahah schemes dominates the financing channeled by the sharia banks and followed by mudharabah and musyarakah. Murabahah financing is considered lower risk compared to the financing of profit sharing systems such as mudharabah and musyarakah contracts. This causes murabahah contracts become dominant in sharia banking.

Basically, murabahah is a buying and selling agreement between the bank and the customer. The bank buys the required item and then sells it at the acquisition price plus the profit margin. In terms of profit sharing, the bank provides financing based on profit sharing (mudharabah) and equity (musyarakah). Thus, different characteristics of sharia financing contracts indicate different levels of risk so that financing policies have an effect on financing risk. 
Wijoyo (2016) states that the macroeconomic factors such as inflation and GDP and the specific condition of the bank affect the NPF. Saniati (2015) shows that inflation has a positive effect on NPF. Setyowati shows that GDP significantly and negatively effects non-performing loans (see Ihsan 2011). On the internal side of Islamic banking, it can be analyzed with the achievement by looking at the financial ratios. Financial ratios affecting NPF level are capital adequacy ratio (CAR) and operational cost to operating income (Auliani 2016). Besides, Addina (2016) shows that Return on Assets (ROA) and bank size negatively affect NPF. Therefore, previous studies imply some of the internal sharia banking e.g. CAR BOPO, bank size as well as ROA and external factors may significantly affect the NPF. The external factor denotes to the macroeconomic variables such as GDP and inflation.

The value of NPF which tends to increase annually with a value i.e. already close to the maximum limit set by Bank Indonesia of 5 percent is able to lead to the inefficiency of the banking system and in the long run, will have an impact on the sustainability of the bank. Therefore, the analysis of NPF factors should be reviewed as a preventive measure and risks controller of business activities. Some previous studies analyzes factor affecting NPF in sharia banks by using general data set provided by OJK. However, this study attempts to analyze factor affecting NPF by using individual data provided by nine sharia banks in Indonesia. Based on the description, then the problem statement that can be raised in this study are: Firstly, how the developments of NPF in sharia Bank? Second, what factors affect the NPF in sharia Bank?

The type of data used in this study is secondary data in the form of time series data quarter period first quarter 2012 until third quarter 2016 and cross-section data of nine sharia Bank. 
Sharia banks which became the object of this research are PT Bank Muamalat Indonesia, PT Bank Syariah Mandiri (BSM), PT Bank Negara Indonesia Syariah (BNI Syariah), PT Bank Central Asia Syariah (BCA Syariah), PT Bank Rakyat Indonesia Syariah (BRI Syariah), PT Panin Syariah, PT Bank Mega Syariah, PT Bank Jabar Banten Syariah and PT Bukopin Syariah. The data used in this study are: Return on Assets (ROA), the ratio of revenue sharing financing to total income financing (RR), Capital Adequacy Ratio (CAR), Operational Cost to Operating Income (BOPO), Net Operational Margin (NOM) Banksize, inflation, and Gross Domestic Product (GDP). Data obtained from various sources include data derived from the financial statements of personal sharia banks, financial services authority, central bureau of statistics and Bank Indonesia.

The methods of analysis used in this research are descriptive and quantitative analysis method. Descriptive analysis is used to see the developments of NPF level in sharia banking. Descriptive analysis method presents images/graphs in the form of data plots to show the conditions of movement and correlation of each variable. The quantitative analysis used in this research is static panel data analysis method. Data panel analysis method is used to obtain the factor affecting NPF by using panel data. Panel data is the combination of cross-section and time-series data used in this research. Quantitative analysis is conducted by using Microsoft Excel and Eviews 8.

\section{Sharia Financing}

According to Wangsawidjaja (2017), one of the main tasks of sharia banks is to distribute financing, i.e to provide loan facilities to fund the deficit unit. Related to that, Allah swt. has said in al-Quran surah al-Hadīd verse 11, which means: 
"Whoever gives a virtuous loan to Allah will receive double from Him in addition to an honorable reward"

In general, there are three types of financing applied by sharia banking, including:

1. Buying and selling principles

a) Bai' al-Murābahah, is the distributions of the fund in the form of buying and selling. The bank will buy the goods the service user needs and then sell them back to the service user at an inflated price according to the profit margin set by the bank, and the service user can repay the goods. The amount of flat installment in accordance with the contract at the beginning and the amount of installment of the basic price plus the agreed margin.

b) Bai' al-Salam, The Bank will buy the required goods in the future, while the payment made in advance. Items purchased must be measured and weighed clearly and specifically, and the determination of the purchase price based on the full pleasure between the parties.

c) Bai' al-Istishnā', is a special al-Salām form in which the price of goods can be paid on contract, paid in installments, or paid in the future. The bank binds each the buyer and seller separately, unlike al-Salam where all parties are tied together from the start. Accordingly, the bank as the party carrying the goods is responsible to the customer for the misconduct of the work and the guarantee arising from the transaction.

2. Rent Principles

a) Al-Ijärah is a contract for the transfer of the right to goods and services through the payment of the rents, without being followed by the transfer of ownership of the goods itself. 
b) Al-Ijārah al-Muntahia bi al-Tamlīk along with ijārah is a contract of transfer of rights to goods and services through the payment of the rents, but at the end of the lease, there is a transfer of ownership of the leased goods.

3. Profit Sharing Principles

a) Mudhārabah Financing. Mudhārabah comes from the word dhäraba, which means hitting or walking. According to Karim (2010), mudhärabah is a form of contract between two parties where one party as the owner of the capital and entrust the amount of the capital to be managed by the second party, i.e. business actors in order to gain profit. Mudhärabah transactions do not require the presences of shähibul māl representatives in project management. Mudhārib should act cautiously and be responsible for any losses incurred due to the negligence. The profits earned are divided according to the agreed portion, whereas in the case of losses will be borne entirely by the owner of the fund, and the manager of the lost funds in mind and energy.

b) Musyārakah Financing. According to Tarsidin (2010), musyārakah is a contract of cooperation between two or more parties for a particular business in which each party contributes funds with the agreement that the benefits and risks will be borne together according to the agreement. Profit or loss should be clearly identified and shared according to the agreement.

Financing is a process from analysis of the financing feasibility until the realizations. However, the realization of the financing is not the last stage of the financing process. After the realizations of the financing, sharia banks need to monitor and supervise the financing, because in the term of is not impossible 
for problems to be occurred due to several reasons. Sharia banks should be able to analyze the causes of the problems so they can make an effort to reinvent the qualities of the financing.

\section{Financing Quality}

According to Bank Indonesia regulations Number 8/21/ PBI/2006 (Bank Indonesia 2006) concerning quality assessment of commercial banks conducting business activities based on sharia principles, there are two types of financing based on financing quality.

First, "performing financing"; It is is categorized into two qualities: current quality and quality that must be given a special attention. Second, "non-performing financing"; it is a financing that is categorized into three qualities: sub-standard quality, doubtful quality, and bad debt financing.

According to Bank Indonesia regulation number 8/21/ PBI/2006 concerning quality assessment of commercial banks conducting business activities based on sharia principles article 9 paragraph 2, the quality of productive assets in the form of financing is divided into 5 groups, i.e. current (L), under special attention (DPK), substandard (KL), doubtful (D), bad debt (M).

Table 2

Summary of financing quality criteria

\begin{tabular}{|c|c|c|}
\hline No & Financing Quality & Criteria \\
\hline 1 & Current & $\begin{array}{l}\text { a. Installments and loan principal are paid } \\
\text { on time } \\
\text { b. Have an active mutation account } \\
\text { c. Included as financing with cash collateral }\end{array}$ \\
\hline 2 & $\begin{array}{l}\text { Under special } \\
\text { attention }\end{array}$ & $\begin{array}{l}\text { a. Installments and loan principal are still in } \\
\text { arrears, but not exceeding } 90 \text { days } \\
\text { b. Account movements are still relatively ac- } \\
\text { tive }\end{array}$ \\
\hline
\end{tabular}




\begin{tabular}{|c|c|c|}
\hline No & Financing Quality & Criteria \\
\hline & & $\begin{array}{l}\text { c. Sometimes an overdraft occurs or a nega- } \\
\text { tive balance on a demand deposit account } \\
\text { that cannot be paid in full } \\
\text { d. Rarely violate contracts that have been } \\
\text { agreed } \\
\text { e. Supported by new loans }\end{array}$ \\
\hline 3 & Substandard & $\begin{array}{l}\text { a. Unpaid installments and loan principal } \\
\text { exceeds } 90 \text { days } \\
\text { b. An overdraft often takes place } \\
\text { c. Breaking the contract agreement more } \\
\text { than } 90 \text { days } \\
\text { d. The existence of an indicator of financial } \\
\text { problems faced by the debtor/borrower } \\
\text { e. Weak loan documentation }\end{array}$ \\
\hline 4 & Doubtful & $\begin{array}{l}\text { a. Unpaid installments and loan principal } \\
\text { exceeds } 180 \text { days } \\
\text { b. Overdrafts are permanent } \\
\text { c. Weak documentation of financing, both } \\
\text { for financing agreements and binding of } \\
\text { warranties } \\
\text { d. The existence of wan prestasi exceed } 180 \\
\text { days }\end{array}$ \\
\hline 5 & Bad Debt & $\begin{array}{l}\text { a. Unpaid installments and loan principal } \\
\text { exceeds } 270 \text { days } \\
\text { b. The operational loss experienced was } \\
\text { closed using new loans } \\
\text { c. Warranties cannot be redeemed at the fair } \\
\text { value, in terms of law or under market } \\
\text { conditions }\end{array}$ \\
\hline
\end{tabular}

Source: Peraturan Bank Indonesia Nomor 8/12/PBI/2006

\section{Non-Performing Financing}

According to the Dictionary of Bank Indonesia, non-performing loans (NPLs) or non-performing financing (NPF) are non-performing loans consisting of substandard, doubtful and loss credits (Bank Indonesia 2017). The NPL term is for commercial banks, while NPF for sharia banks. NPF is one of the 
indicators used to measure the level of health of a banking institution (measure the soundness of a banking institution). The levels of problem financing are reflected in the NPL or NPF ratio, which is the formulations of:

$$
N P F=\frac{\text { Financing }(K L, D, M)}{\text { Total of financing }}
$$

NPF is very influential against the control of the cost and also affect the financing policy that will be done by the bank itself. NPFs can have an unfavorable impact if the NPF values are large. The amount of NPL or NPF ratio allowed by Bank Indonesia is a maximum of 5 percent. If it exceeds 5 percent, it will affect the rating of the health of the bank. Therefore, sharia banks need financing management capabilities.

\section{Factors Affecting the NPF}

Factors that are expected to influence NPF are Return on Assets (ROA), Ratio of revenue sharing financing (RR), Bank size, Capital Adequacy Ratio (CAR), Operating Cost to Operating Income (BOPO), Net Operational Margin (NOM) Inflation, and Gross Domestic Product (GDP). The following describes the relationship between the independent variables used in this study with the dependent variable:

1. Non-performing financing relations with Return on Asset (ROA)

Return on Assets (ROA) is one of the profitability ratios. Profitability is the basis of the existences of the relationship between operational efficiency with the qualities of services produced by a bank. ROA shows the ratio to measure the bank's management capability in gaining overall profits. The greater the ROA is, the better the company's performance, because of the greater return. With the increased in profits 
obtained by the banks, it will be easier to overcome the risks, so the risk of non-performing financing will decrease.

2. Non-performing financing relations with RR

Types of financing profit loss sharing (PLS) consists of mudharabah and musyarakah financing where the financing of PLS has a high risk, this is because in this contract the profit earned by shahibul mal (bank) is relatively uncertain even the bank must be ready to bear the loss. The absences of a guarantee provision in the PLS financing cause the bank to face the risk of moral hazard and adverse selection due to the asymmetric information. Setting a ratio that will give high returns for risky types of PLS means that it has prevented the occurrences of moral hazard risks, in this case, an increasing NPF ratio, for irresponsible debtors. The higher the return ratio, the better the bank policies in anticipating the possibilities of moral hazard (Nasution and Wiliasih 2007).

3. Non-performing financing relations with Capital Adequacy Ratio(CAR)

The CAR describes an indicator of the bank's ability to cover its decline in assets as a result of the bank loss caused by risky assets. The higher the CAR value indicates that the bank's capital increases, thus reducing the NPF. This indicates that the increased level of capital adequacy, banks will manage the risks of problem financing more easily, which can decrease the value of NPF.

4. Non-performing financing relations with BOPO

Operational Costs of Operating Income (BOPO) are often called efficiency ratios as they are used to measure management's ability to control operational costs against operating income. So the smaller the ratio of BOPO the more efficient the operational costs incurred by the company. 
5. Non-performing financing relations with Net Operational Margin (NOM)

NOM is a ratio to determine the bank ability to manage its productive assets to produce higher net income. When setting high margins, banks need to consider legal lending limits and appropriate financing analysis according to the level of the financing risk. The higher the pricing of sharia banks in determining the financing margin and the lower the pricing of savings, the higher the risk of the non-performing financing. This is caused by the pricing of the financing that is too high, which can affect the inability of the customers to pay off the installments. In addition, low profit-sharing rates can cause third party funds to decrease.

6. Non-performing financing relations with bank size

In the banking sector, the size is more likely seen from the total assets because the main products are financing and investment. According to Firmansyah (2015), banks that have a large size or more assets have the possibilities to generate greater profits.

7. Non-performing financing relations with Inflation

One of the effects of inflation is on the real income of the community. There are groups of people who are able to increase the real income but most people experience a decline in the real income. The worsening of the real income of this society will affect the problematic financing, because it will be difficult for the community to pay the obligations to the bank.

8. Non-performing financing relations with Gross Domestic Product

Gross Domestic Product (GDP) used to measure all goods and services produced in a country's economy over a time. In the events of a decline in GDP, where there is a 
decrease in sales and corporate earnings, it will affect the ability of the company to return the loan. This will lead to an increase in non-current financing (Rahmawulan 2008). Meanwhile, GDP growth can increase the ability of customers in fulfilling their obligations so that NPF decreases.

\section{Research Methods}

\section{Data Panel}

The estimation method for panel data can use three approaches: Pooled Least Squared, Fixed Random Effect, and Random Effect Model. To find the exact model can use Chow test and Hausman test.

\section{Research Model}

Looking at the results of earlier empirical studies and considering the assumptions that the panel data model refers to, the variables that are expected to affect non-performing financing at sharia commercial banks are internal banking variables including financing policies and external variables. Here are the main models in this study:

$$
\begin{aligned}
& N P F_{i t}=a+a_{1} R R_{i t}+a_{2} N O M_{i t}+a_{3} R O A_{i t}+ \\
& a_{4} L N B A N K S I Z E_{i t}+a_{5} C A R_{i t}+a_{6} B O P O_{i t}+ \\
& a_{7} L N G D P_{t}+a_{8} I N F_{t}+\varepsilon_{i t}
\end{aligned}
$$

\begin{tabular}{|c|c|}
\hline $\mathrm{NPF}_{\text {it }}$ & : Non Performing Financing (percent) \\
\hline $\mathrm{RR}{ }^{\mathrm{t}}$ & : Ratio return (percent) \\
\hline $\mathrm{NOM}_{\text {it }}$ & : Net Operational Margin (percent) \\
\hline ROA. ${ }^{\text {it }}$ & : Return on Assets (percent) \\
\hline LNBANNKSIZE $_{\text {it }}$ & : Ln total asset (percent) \\
\hline $\mathrm{CAR}_{\mathrm{it}}$ & : Capital Adequacy Ratio (percent) \\
\hline BOPOit & : Level of efficiency (percent) \\
\hline LNGDP $_{\text {it }}$ & : Gross Domestic Product (percent) \\
\hline $\mathrm{INF}_{\text {it }}$ & : Inflation (percent) \\
\hline & : Cross section \\
\hline $\mathrm{t}$ & : time series \\
\hline $\mathrm{a} ; \mathrm{a}_{1} ; \varepsilon_{\mathrm{it}}$ & : Intersep; Konstanta; eror \\
\hline
\end{tabular}

Notes: 


\section{Operational Definition of Variables}

The variables used in this research model are classified into two, internal and external banking. The operational definitions of the variables used are as follows:

a. Gross Non-Performing Financing (NPF) is a ratio of the earning asset qualities that measure the ability of the bank management in managing the non-performing financing (substandard, doubtful and loss) provided by the bank.

b. $\mathrm{RR}$ is a comparative picture of the income generated by the profit loss sharing financing with the total return on financing. NOM is the ratio used to determine how much the bank's ability to manage all its productive assets to generate higher profits.

c. Return on Assets (ROA) measures the ability of the bank management in gaining profit (profit before tax) generated from the average total assets of the bank. Profit before tax is net income from pre-tax operating activities.

d. Bank size is a proxy of the total assets of each bank.

e. Capital Adequacy Ratio (CAR) measures the capital adequacy of a bank to support assets that contain or generate financing risks.

f. Operational Costs of Operating Income (BOPO) measures the management's ability to control operational costs against operating income.

g. Inflation represents a general price increase and occurs continuously. In this study, the inflation rate used is the average rate of inflation per 3 months.

h. GDP reflects the economic performance in producing an item in a certain period. This research use quarterly GDP value with constant price. 


\section{Model Evaluation Based on Econometrics Criteria}

Tests of classical assumption violations consist of multicolinearity test, normality, heteroscedasticity and autocorrelation. The model is said to be good if it is free from the violation of the classical assumption.

\section{Table 3}

Estimation results against violation of classical assumptions

\begin{tabular}{ccccc}
\hline \multirow{2}{*}{$\begin{array}{c}\text { Probability } \\
\text { Chi- }\end{array}$} & \multicolumn{4}{c}{ Test the Best Model } \\
\cline { 2 - 5 } Squared & $\begin{array}{c}\text { Durbin } \\
\text { Watson }\end{array}$ & $\begin{array}{c}\text { Sum Square } \\
\text { Resid } \\
\text { (Weighted) }\end{array}$ & $\begin{array}{c}\text { Sum Square } \\
\text { Resid } \\
\text { (Unweighted) }\end{array}$ & $\begin{array}{c}\text { Probability } \\
\text { Jarque Bera }\end{array}$ \\
\hline Model 1 & 1.695347 & 157.7606 & 207.8044 & 0.067716 \\
\hline
\end{tabular}

Source: Output eviews 8

Based on the output in Table 3 to the classical assumption test, the following results are obtained:

a. Normality test

From the Skewness/Kurtosis, the result shows that the probability of the JarqueBera is more than the true alpha level of 0.05 , so that there is enough evidence to reject $\mathrm{H} 0$. Thus, the residuals in the research are spreads normally.

b. Multicollinearity Test

The test of multicollinearity problem can be seen from the criterion which shows the value of R2 (high square R2) but from the estimation result of many research variables, which is not significant. In this research, the multicollinearity can be seen from correlation coefficient value by using e-views software 8 . In the output, the result shows that there is no correlation value exceeding 0.8 on the independent variables. Thus, the requirements have been met. 
c. Heteroscedasticity Test

Heteroskedasticity can be known by comparing Sum Square Resid on Weight Statistic with Sum Squared Resid Unweighted Statistic. If Sum Square Resid on Weight Statistic is smaller than Sum Squared Resid Unweighted Statistic, there is heteroscedasticity. The model in the study using GLS Cross-Section so that direct heteroskedasticity problems can be corrected so that the model is free from heteroscedasticity problem.

d. Test Autocorrelation

The autocorrelation test can be done by looking at Durbin Watson (DW). Models that are free from autocorrelation should be in an autocorrelation-free area that has a DW-stat value between DU $<$ DW $<4$-DU. The result of regression in this research shows that Durbin Watson Statistic (DW-stat) value in each model is not in autocorrelation free area so that there is autocorrelation in the model. This autocorrelation problem is overcome by GLS weighting.

\section{The Analisys of Non-Performing Financing Development of Sharia Banking}

Bank as an intermediary institution has a duty in channeling the financing to the community. Distribution of the financing will cause risks that must be considered by the bank, one of them by controlling the value of non-performing financing. Gross NPF Condition at sharia commercial bank shows a fluctuating trend every year. Referring to Bank Indonesia regulation number 15/2/ $\mathrm{PBI} / 2013$ about status determination and follow up supervisory on sharia banks (Bank Indonesia 2013). The regulation sets the maximum limit of NPF of 5 percent. Looking at the data presented in the picture, some banks have a Gross NPF value above 5 percent. Sharia commercial banks should pay more attention to this because high NPFs can give a loss to the banks. 
Figure 3

Development of non-performing financing at Sharia Banks

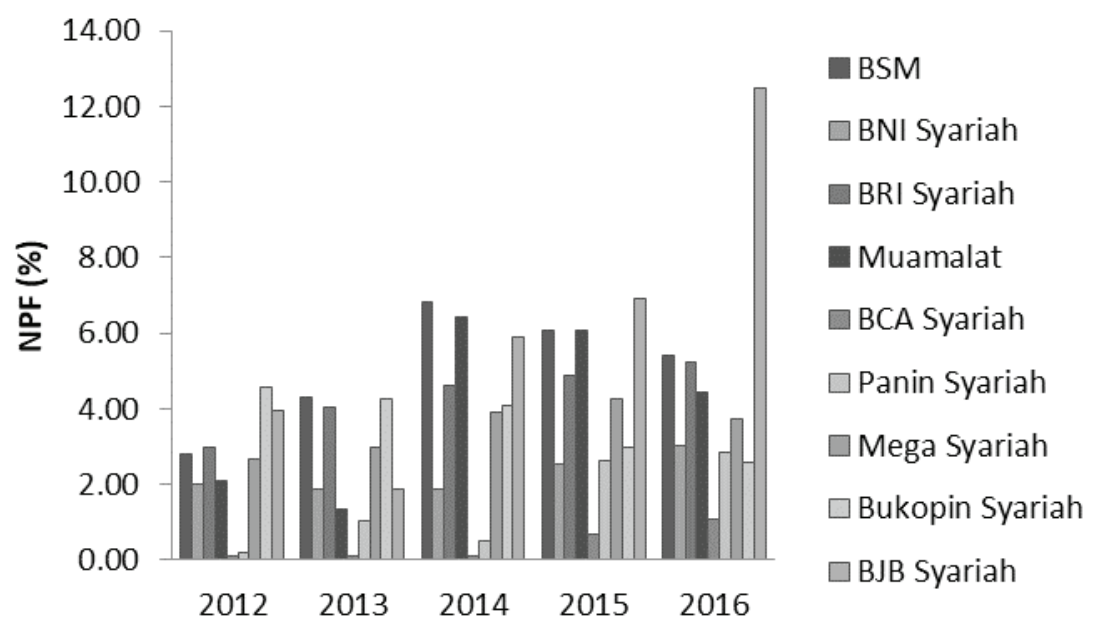

In Figure 3 it can be seen that NPF in sharia banks have an average NPF rate of 0 until 7 percent. By 2015 and 2016, the highest NPF rate is owned by BJB Syariah Bank. This is caused by the decline in oil prices and followed by a decline in commodity prices that becomes complementary such as coal and oil substitution goods such as natural rubber so that oil companies and supporting industries are experiencing financial difficulties, even some companies have experienced bankruptcy demands due to the inability of the company to fulfill its financial obligations to the creditor.

The sharia industry, particularly sharia banking, is an industry that has a direct impact on the decline in the commodity prices because of its intensive financing portfolio with regard to the commodities, including BJB Syariah. A decrease in the quality of the financing encourages BJB Syariah to increase the allowance for the eliminations of productive assets, resulting in a decrease in profit in 2015. In addition to reserve costs, cost and 
high pressures that ultimately affect cost efficiency as reflected by the rising BOPO ratio also affect profits (Bank BJB Syariah 2017).

In 2014, Bank Syariah Mandiri owns the highest NPF rate by the end of the year with an NPF value of 6.84 percent. This is due to the expansions of financing in the SME sector undertaken by BSM, which is $67 \%$ of the total financing. At this year, there is also a slowdown in national economic growth that has a major impact on the business development of BSM debtors. In addition to the internal side of the bank, due to the rapid growth of BSM without fully accompanied by the speeds of infrastructure, during the last three years BSM experienced a decrease in performance, especially NPF Gross increased from 2.82\% (2012), $4.32 \%$ (2013) and 6, 84\% (2014) (BSM 2017).

In addition, Bank Muamalat's NPF has a fluctuating development every year since 2014. In 2014 the value of NPF in Muamalat reached 6.43 percent. Similar to other sharia banks, the cause is the depressed global commodity prices that are the mainstay of Indonesian exports, especially coal. In addition, the cause of the high level of NPF Muamalat in that year was the bankruptcy of Batavia Air. Bank Muamalat funded the airline for Rp 120 billion with outstanding financing when Batavia went bankrupt was Rp 186 billion. Muamalat's NPF has experienced an improvements trend since the second quarter of 2015, but until 2016 NPF is still high in the corporate sector, especially in the mining sector. Financial markets are still in dire straits as commodity prices are still depressed, which causes the growth rate of the banks, in general, is very low (Bank Muamalat Indonesia 2017).

\section{Analysis of Factors Influencing NPF of Sharia Banking}

The model in this study was conducted to see the effect of 
internal and external variables on the level of Non-Performing Financing (NPF) in the first quarter 2012 until the third quarter 2016. The results of this study showed that RR, ROA, inflation, GDP, CAR, BOPO, and banksize Significantly to NPF of sharia banking. This research shows the value of $\mathrm{R}^{2}$ in model estimation with high enough number that is 0.978106 , it means 97.8 percent diversity of NPF variable can be explained by independent variables in the model and the rest is explained by other variables outside the model. The summary of estimation results can be seen in Table 4 .

\section{Table 4}

Estimation result of internal
and external factors of banking to NPF

\begin{tabular}{lcr}
\multicolumn{1}{c}{ Variable } & Coefficient & Probability \\
\hline INFLATION & $-0.125498^{*}$ & 0.0002 \\
LNGDP & $7.885820^{*}$ & 0.0000 \\
CAR & $-0.023134^{*}$ & 0.0002 \\
BOPO & $0.037532^{*}$ & 0.0001 \\
LNBANKSIZE & $-0.404362^{* *}$ & 0.0303 \\
RR & $-0.584148^{*}$ & 0.0000 \\
ROA & $-0.343879^{*}$ & 0.0019 \\
NOM & 0.026986 & 0.3135 \\
\hline
\end{tabular}

Source: Output eviews 8

Notes: * and "significant at level of 5 percent and 1 percent respectively

Based on the output in Table 4, it is known that the inflation variable has a negative and significant effect on the NPF with a coefficient of -0.125498 . This relationship indicates that when inflation increases 1 percent, the NPF level will decrease by 0.125498 percent with the assumption that other variables are considered constant. The results of this study are not in accordance with the initial hypothesis but in line with the results 
of research Firmansyah (2015) stating that inflation has a significant negative effect on NPF. According to (Oktaviani and Novianti 2014) high inflation rates will lead to higher nominal interest rates, which will ultimately lower real money balances. If society holds a relatively low real money balance, then the public will withdraw the money stored in the bank. According to (Huda et al. 2008) the impact of inflation causes people are reluctant to save because the value of the currency is declining. This will lead to a decrease in third party funds or bank assets so that the distribution of funds will decrease. The decrease in financing disbursed will also reduce the value of NPF.

GDP variable has a significant positive effect on NPF with coefficient of 7.885820 . This relationship indicates that when GDP increases 1 percent, the NPF level will rise by 7.885820 percent with the assumption that other variables are considered constant. The results of this study are not in accordance with the initial hypothesis but in line with the results of research Firmansari and Suprayogi (2015) which indicates that GDP variables have a significant positive effect on NPF. If the economic conditions are good, with increasing GDP it will affect people's income. Increased public income will affect the bank's DPK because people tend to be able to invest. As the DPK increases, the bank is able to expand its financing so that the financing risks faced by banks will be greater.

CAR variables have negative and significant effect on NPF with coefficient of -0.023134 . This relationship indicates that when CAR increases 1 percent, the NPF level will decrease by 0.023134 percent with the assumption that other variables are considered constant. The results of this study are in accordance with the initial hypothesis and in line with the results of research (Sukmana 2015) which states that CAR has a significant negative effect on NPF in Islamic banks. This shows that the CAR is 
a financial performance that describes the ratio of capital adequacy to risk-bearing assets, so the higher the CAR value, the NPF value will decrease.

BOPO variable has a significant positive effect on NPF with coefficient 0.037532 . This relationship shows that when BOPO increases 1 percent, the NPF level will rise by 0.037532 percent assuming other. The variables are considered constant. The results of this study are in accordance with the initial hypothesis and in line with the results of research Ferawati (2016) which indicates that the variable BOPO have a significant positive effect on NPF. When BOPO value increases, this means that the bank has difficulties in controlling its operational costs and of course this will disrupt the operation of the sharia bank itself and will affect the NPF.

Bank size variables have a negative and significant influence on the level of NPF in sharia banks. Bank size coefficient is -0.404362 . This means that an increase in assets of 1 will decrease the NPF by 0.404362 with other factors assumed to be constant. The results of this study are in accordance with the initial hypothesis and in line with the results of (Pratina 2015) which shows that total assets have a significant negative effect on NPF. Banks that have large total assets tend to be easy to expand financing which will also lead to increased revenue. In addition to financing expansions, banks will also more easily obtain third-party funds. This will help banks manage their business and financing risks.

RR variable gives negative and significant influence to NPF with a coefficient equal to -0.584148 . This relationship indicates that when RR increases 1 percent, the NPF level will decrease by 0.584148 percent with the assumption that other variables are considered constant. The results of this study are in accordance with the initial hypothesis and supported by the results of the 
Kinasih (2013) study indicating that the RR variable has a significant negative effect on the NPF because this variable reflects the bank's prudent level in conducting risky financing. It indicates the commitment and seriousness of the bank in preventing the occurrence of a moral hazard and adverse selection.

ROA variable has a negative and significant influence on NPF with a coefficient of -0.343879 . This relationship shows that when ROA increases 1 percent, the NPF level will decrease by 0.343879 percent assuming other variables are considered constant. The results of this study are in accordance with the initial hypothesis and in line with the research results (Setiawan and Putri 2013) which indicates that the ROA variable has a significant negative effect on NPF. The greater the ROA shows the company's performance the better, because of the greater the return. With the increase in profits obtained by banks, the bank will be easier in overcoming the risks faced, so the risk of non-performing financing will decrease.

The NOM variable has a positive but insignificant effect on the NPF. These results are in line with the results of the (Kinasih 2013) study which shows the NOM variable of XYZ bank, in the long run, has no significant effect. This is because at the time of high NOM will increase the profitability of banks so that banks will be able to manage the risk well that makes the NPF value does not increase.

\section{Conclusion}

This article aims to analyzes the factors influencing non performing financing at sharia banking. There are internal and macroeconomic variables that influence non-performing financing at sharia banks. Firstly, the internal variables of the bank that affect Non-Performing Financing are RR, ROA, CAR, BOPO, and Bank size. While RR, Bank size, CAR and ROA variables have 
a negative and significant effect on NPF, BOPO variable gives positive and significant influence to NPF.

Second, macroeconomic variables of the bank that affect non-performing financing are inflation and GDP. While inflation has a negative and significant effect on NPF, GDP variable gives positive and significant influence to NPF.

The recommendations that writer can provide are as follows: first, sharia banks should maintain the financial performance and set appropriate financial policies by monitoring the Bank size, BOPO, CAR, ROA, and RR ratios. This is because the internal condition of the bank becomes the thing that affects the ability of banks in managing the NPF. The higher NPF may lead to the inefficiency of the banking system and in the long run will have an impact on the sustainability of the banks. Therefore, it is crucial to maintain the factors affecting NPF from internal banks so they are able to prevent higher NPF value in the future. In addition, regulators have to control the macroeconomic variable, particularly inflation rate.

Second, further research can be done more profound on financing, which has a high NPF value based on the type of the financing or the type of the contracts. Besides, many previous studies conducted about NPF, but few of them discuss about factor affecting NPF from the customer side. Therefore, factor analysis that affects NPF from the customer side may conduct for further research since banks need to understand the reason customers are not able to repay their installment.

The data of this studies is limited by nine of sharia banks (BUS) in Indonesia. The remaining BUS and rural banks (BPRS) have not been reached since limited data provided. Thus, for the further studies, it is recommended to add all sharia banks including (BUS), sharia business unit (UUS) as well as rural banks (BPRS). 
JAENAL EFFENDI, USY THIARANY, TITA NURSYAMSIAH

\section{Bibliography}

Auliani, Mia Maraya. 2016. “Analisis Pengaruh Faktor Internal Dan Faktor Eksternal Terhadap Tingkat Pembiayaan Bermasalah Pada Bank Umum Syariah Di Indonesia Periode Tahun 2010-2014.” Universitas Diponegoro.

Bank BJB Syariah. 2017. "Laporan Keuangan Triwulan.” Bank BJB Syariah. http://bjbsyariah.co.id.

Bank Indonesia. 2006. "Peraturan Bank Indonesia No. 8/21/ PBI/2006 Penilaian Kualitas Aktiva Bank Umum Yang Melaksanakan Kegiatan Usaha Berdasarkan Prinsip Syariah.” Bank Indonesia. http://www.bi.go.id/id/peraturan/ perbankan/Pages/pbi_82106.aspx.

- 2013. "Peraturan Bank Indonesia Nomor 15 /2/ PBI/2013 Tanggal 20 Mei 2013 Tentang Penetapan Status Dan Tindak Lanjut Pengawasan Bank Umum Konvensional - Bank Sentral Republik Indonesia.” Bank Indonesia. http://www.bi.go.id/id/peraturan/perbankan/Pages/ PBI_15_2_PBI_2013.aspx.

_. 2017. "Kamus Bank Sentral Republik Indonesia.” Bank Indonesia. http://www.bi.go.id/id/Kamus.aspx.

Bank Muamalat Indonesia. 2017. "Laporan Keuangan Triwulan.” Bank Muamalat Indonesia. http://bankmuamalat. co.id.

BSM. 2017. "Laporan Keuangan Triwulan.” Bank Syariah Mandiri. http://syariahmandiri.co.id.

Ferawati, Dwi. 2016. "Faktor-Faktor Yang Mempengaruhi Non Performing Financing Pada Bank Umum Syariah Di Indonesia Pada 2012-2015.” UIN Sunan Kalijaga .

Firmansari, Daisy, and Noven Suprayogi. 2015. "Pengaruh 
Variabel Makroekonomi Dan Variabel Spesifik Bank Terhadap Non Performing Financing Pada Bank Umum Syariah Dan Unit Usaha Syariah Di Indonesia Periode 20132014." Jurnal Ekonomi Syariah Teori Dan Terapan 2 (6). doi:10.20473/VOL2ISS20156PP\%P.

Firmansyah, Irman. 2015. "Determinant of Non Performing Loan: The Case of Islamic Bank in Indonesia." Buletin Ekonomi Moneter Dan Perbankan 17 (2): 241. doi:10.21098/bemp.v17i2.51.

Huda, Nurul, Handi Risza Idris, Mustafa Edwin Nasution, and Ranti Wiliasih. 2008. Ekonomi Makro Islam: Pendekatan Teoretis. Jakarta: Kencana Prenadamedia Group.

Ihsan, M. 2011. "Pengaruh Gross Domestic Product, Inflasi, Dan Kebijakan Jenis Pembiayaan Terhadap Rasio Non Performing Financing Bank Umum Syariah Di Indonesia Periode 2005 Sampai 2010.” Universitas Diponegoro.

Karim, Adiwarman. 2010. Bank Islam: Analisis Fiqih Dan Keuangan. Jakarta: Rajagrafindo Persada.

Kinasih, SW. 2013. "Analisis Faktor Determinan Tingkat Risiko Pembiayaan Bank Syariah Pada 2005-2012.” Universitas Indonesia.

Nasution, Mustafa Edwin, and Ranti Wiliasih. 2007. "Profit Sharing Dan Moral Hazard Dalam Penyaluran Dana Pihak Ketiga Bank Umum Syariah Di Indonesia." Jurnal Ekonomi Dan Pembangunan Indonesia 7 (2): 231-55. doi:10.21002/JEPI.V7I2.175.

OJK. 2017. "Statistik Perbankan Syariah - Desember 2016." Otoritas Jasa Keuangan. http://www.ojk.go.id/id/kanal/ syariah/data-dan-statistik/statistik-perbankan-syariah/ 
JAENAL EFFENDI, USY THIARANY, TITA NURSYAMSIAH

Pages/Statistik-Perbankan-Syariah---Desember-2016.aspx.

Oktaviani, Rina, and Tanti Novianti. 2014. Teori Makroekonomi 1. Bogor: IPB Press.

Pratina, DG. 2015. "Faktor-Faktor Yang Memengaruhi Tingkat Non Performing Financing Pada Bank Pembiayaan Rakyat Syariah Di Indonesia.” Institut Pertanian Bogor.

Rahman, AF, and R Rochmanika. 2012. "Pengaruh Pembiayaan Jual Beli, Pembiayaan Bagi Hasil, Dan Rasio Non Performing Financing Terhadap Profitabilitas Bank Umum Syariah Di Indonesia." Universitas Brawijaya.

Rahmawulan, Y. 2008. "Perbandingan Faktor Penyebab Timbulnya NPL Dan NPF Pada Perbankan Konvensional Dan Syariah Di Indonesia." Universitas Indonesia.

Saniati, R. 2015. “Analisis Eksternal Dan Internal Dalam Menentukan Non Performing Financing Bank Umum Syariah.” UIN Sunan Kalijaga.

Setiawan, Chandra, and Monita Eggy Putri. 2013. "Non Performing Financing and Bank Efficiency of Islamic Banks in Indonesia." Journal of Islamic Finance and Business Research 2 (1).

Silmi, Addina. 2016. "Pengaruh Variabel Makroekonomi Dan Kinerja Perbankan Terhadap Non Performing Financing Bank Umum Syariah Di Indonesia Periode 2012-2015.” Institut Pertanian Bogor.

Sukmana, Raditya. 2015. "Determinants of Non Performing Financing in Indonesian Islamic Banks.” Working Papers. The Islamic Research and Teaching Institute (IRTI).

Tarsidin. 2010. Bagi Hasil, Konsep Dan Analisis. Depok : Lembaga Penerbit FE UI. 
FACTORS INFLUENCING NPF AT SHARIA BANKING

Wangsawidjaja, A. 2017. Pembiayaan Bank Syariah. Jakarta: Gramedia Pustaka Utama.

Wijoyo, Satrio. 2016. "Analisis Faktor Makroekonomi Dan Kondisi Spesifik Bank Syariah Terhadap Non-Performing Finance.” Jurnal Pendidikan Dan Ekonomi 5 (6): 513-25. 
This page intentionally left blank 